\title{
An Outbreak of Anthracnose Caused by Colletotrichum gloesporioides f.sp. manihotis in Cassava in North Western Tanzania
}

\author{
Magdalena N. M. William ${ }^{1,2}$, Ernest R. Mbega ${ }^{1}$, Robert B. Mabagala ${ }^{{ }^{*}}$ \\ ${ }^{1}$ African Seed Health Centre, Department of Crop Science and Production, Sokoine University of Agriculture, Morogoro, Tanzania; \\ ${ }^{2}$ Maruku Agricultural Research Institute, Bukoba, Tanzania. \\ Email: "rmabagala@yahoo.com
}

Received December $16^{\text {th }}, 2011$; revised January $13^{\text {th }}, 2012$; accepted February $20^{\text {th }}, 2012$

\begin{abstract}
Severe outbreak of anthracnose diseases caused by Colletotrichum gloesporioides f.sp. manihotis on cassava (Manihot esculenta Crantz) occured in north-western Tanzania in October, 2011. Thirteen cassava leaf samples with disease symptoms were collected from Maruku Agricultural Research Institute (MARI) and from farmers. The collected samples were tested for infection using Blotter method. The results indicated that, all 13 leaf samples (100\%) were infected by C. gloesporioides f.sp. manihotis. Three isolates of the fungus per sample were sub-cultured on Potato Dextrose Agar (PDA) for seven days then each isolate was sprayed-inoculated onto 4-week-old sprouting leaves of cassava cuttings, var Mkombozi grown in pots in the screenhouse maintained at $27^{\circ} \mathrm{C}$ and relative humidity of $85 \%-90 \%$. All isolates were pathogenic on cassava and produced similar symptoms as those observed under field conditions. This is the first report of C. gloesporioides f.sp. manihotis a causal agent of anthracnose disease of cassava in Tanzania.
\end{abstract}

Keywords: Anthracnose; Incidence; Cassava; Pathogenicity Tests

\section{Introduction}

Anthracnose caused by Colletotrichum gloesporioides f.sp. manihotis is an important disease of cassava (Manihot esculenta Crantz) in tropical Africa and it can be transmitted through breeder seeds and post-harvest debris in the field [1,2]. The disease has been reported to cause total crop failure where infected propagation materials are used as seed sources [3].

We report the occurrence of $C$. gloesporioides f.sp. manihotis causal agent of anthracnose disease on cassava in Tanzania.

\section{The Disease}

\subsection{Survey and Isolation of Fungi from Cassava Samples}

In early October 2011, cassava (Manihot esculenta Crantz) plants variety Mkombozi were found with necrotic leaf symptoms at Maruku Agricultural Research Institute (MARI), Bukoba, Tanzania. Symptoms included small to medium $(0.25-2.50 \mathrm{~cm})$, irregular to regular necrotic lesions on leaves (Figure 1(a)). Infected leaves turned yellow and detached from stems. Disease incidence was

*Corresponding author.
100 percent in about 10,000 cassava plants planted for seed multiplication program. In mid October, eleven cassava farms around MARI were visited and seven of them (63.6\%) were found with similar disease symptoms.

Thirteen leaf samples (two from MARI and 11 from nearby locations) with disease symptoms were collected, packed in sterile transparent polyethylene bags, labelled and transported to the African Seed Health Centre Laboratory, Morogoro, Tanzania for analysis. The Blotter method [4] was used to test the cassava samples for infection. Leaf samples of about $1 \mathrm{~cm} \times 2 \mathrm{~cm}$ (Figure 1(b)) and/or leaf stalks of about $0.2 \mathrm{~cm} \times 2 \mathrm{~cm}$ were cut and placed on well water-soaked three-layer blotters in Petri dishes (nine pieces per plate) and incubated at $22^{\circ} \mathrm{C}$ $25^{\circ} \mathrm{C}$ for seven days in alternating cycles of $12 \mathrm{~h}$ darkness and light. Identification of the fungi was done based on morphology of the mycelia and conidia observed under the stereo and compound microscopes as described by Mathur and Kongsdal [4].

\subsection{Pathogenicity Tests}

Three isolates per sample were sub-cultured on Potato Dextrose Agar (PDA) for seven days. Then the pure cultures were harvested and grown on V8 juice agar for 


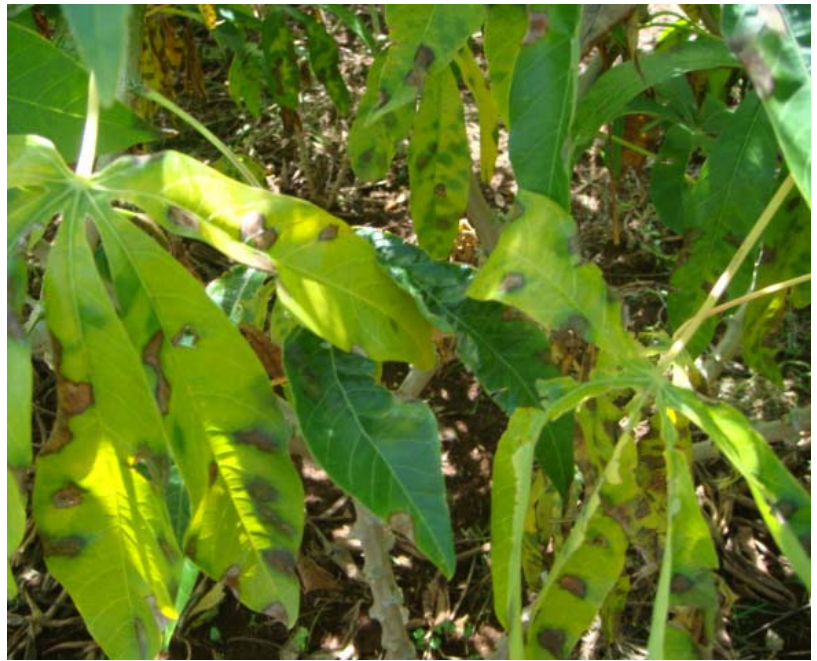

(a)

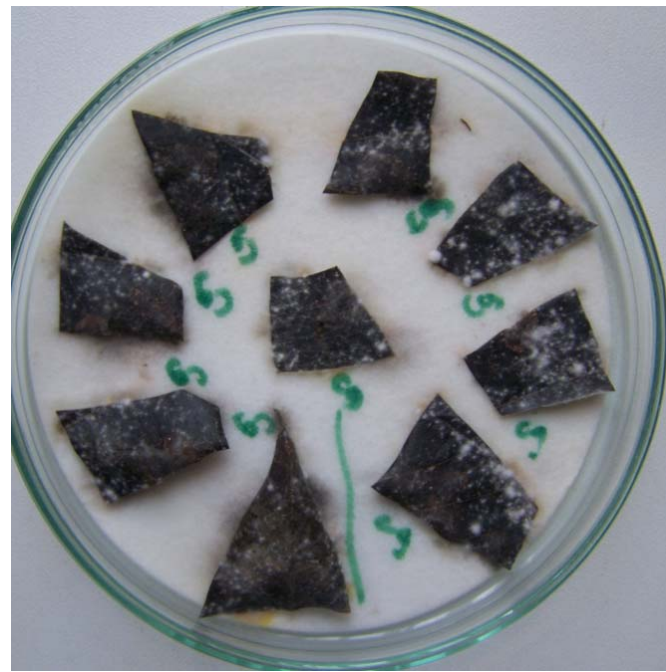

(b)

Figure 1. Symptoms of severe infection caused by Colletotrichum gloesporioides f.sp. manihotis (a), Detection of fungal microorganisms using blotter method (b).

seven days. Suspensions of $10^{6}$ spores/ml were prepared and inoculated by spraying onto the 4-week-old sprouting leaves of cassava cuttings (variety Mkombozi) grown in pots in the screenhouse, set at $27^{\circ} \mathrm{C}$ and relative humidity of $85 \%-90 \%$.

\section{Results and Discussion}

Results indicated that, all thirteen (100\%) cassava leaf samples were infected by C. gloesporioides f.sp. manihotis. The fungus acervuli appeared like pycnidial bodies emerged from leaf stalk surface (Figure 2(a)) as observed at $\times 25$ magnifications of a stereomicroscope (of up to $\times 50$ magnification). Conidia were greyish, hyaline, one celled, straight cylindrical, $6-14 \times 3.5 \mu$ with

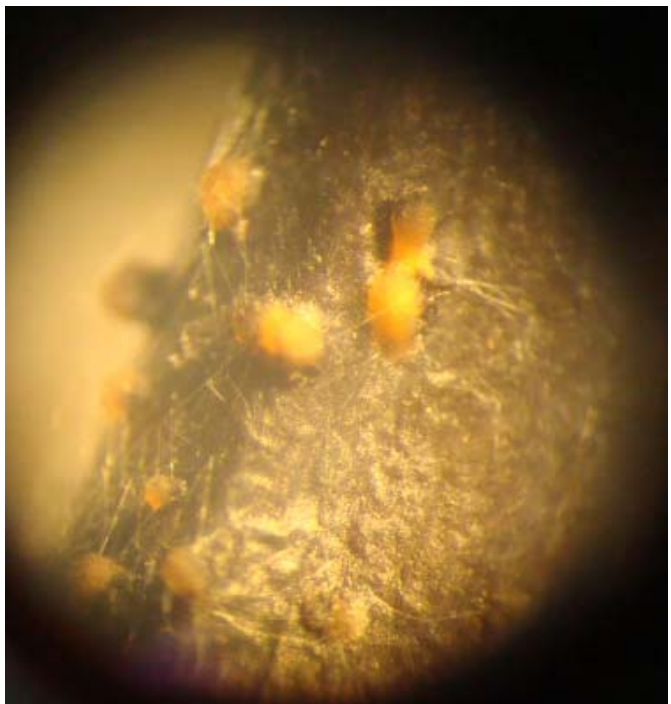

(a)

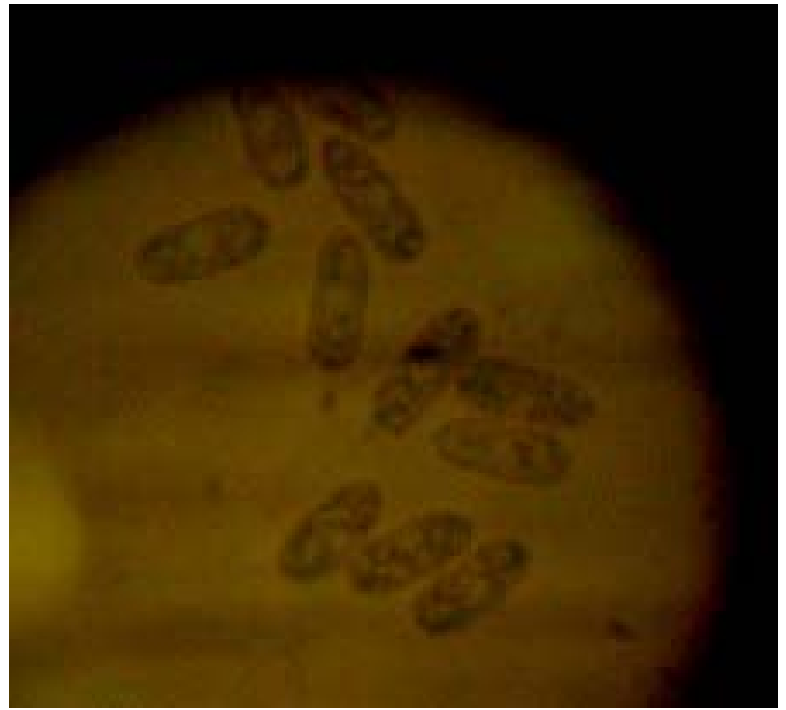

(b)

Figure 2. Acervuli of Colletotrichum gloesporioides f.sp. manihotis on the leaf stalk surfaces at $\times \mathbf{2 5}$ magnification under stereo microcrope (a), Conidia of $C$. gloesporioides f.sp. manihotis observed under compound $(\times 60$ magnification) microscope (b).

rounded ends (Figure 2(b)) at $\times 60$ magnifications.

All 39 isolates proved to be pathogenic on cassava cultivar Mkombozi and produced similar symptoms as those observed under field conditions (Figure 1(a)). Such results complied with Koch's postulates [5]. Anthracnose disease incited by C. gloesporioides f.sp. manihotis on cassava has been reported in many African countries [1,2]. However, literature shows no reports of occurrence of anthracnose caused by C. gloesporioides f.sp. manihotis on cassava in Tanzania. Therefore, this is the first report of this fungal pathogen on cassava in the 
country.

A follow-up of the incidence of anthracnose disease in other cassava growing areas is therefore, urgently needed in order to understand the extent of the problem in Tanzania.

\section{Acknowledgements}

This work was supported by the African Seed Health Centre, Sokoine University of Agriculture, Morogoro, Tanzania.

\section{REFERENCES}

[1] C. N. Fokunang, T. Ikotun, A. G. O. Dixon and C. N. Akem, "First Report of Colletotrichum gloesporioides f.sp. manihotis, Causal of Cassava Anthracnose Disease, Being Seed-Borne and Seed-Transmitted in Cassava," Plant Disease, Vol. 81, No. 6, 1997, pp 695.

doi:10.1094/PDIS.1997.81.6.695C
[2] C. N. Fokunang, A. G. O. Dixon, T. Ikotun, E. A. Tembe, C. N. Akem and R. Asiedu, "Anthracnose: An Economic Disease of Cassava in Africa," Pakistan Journal of Biological Sciences, Vol. 4, No. 7, 2001, pp. 920-925. doi:10.3923/pjbs.2001.920.925

[3] T. Ikotun and S. K. Hahn, "Screening Cassava Cultivars for Resistance to Anthracnose Disease. Tropical Root Crops in Developing Economy," Proceedings of the $9^{\text {th }}$ Symposium of the International Society for Tropic Root Crops, Accra, 20-26 October 1991, pp. 178-183.

[4] S. B. Mathur and O. Kongsdal, "Common Laboratory Seed Health Testing Methods for Detecting Fungi,” Danish Government Institute of Seed Pathology for Developing Countries, Copenhagen, 2003.

[5] L. W. O’Garro, J. P. Gore and E. Ferguson, "Races of Xanthomonas campestris pv. vesicatoria Overcoming the Gene Bs2 for Bacterial Spot Resistance in Pepper, Prevalent on Capsicum Chinese in Barbados and Grenada and Weakly Pathogenic on Bell Pepper and Tomato in the Field,” Plant Pathology, Vol. 48, No. 5, 1999, pp. 588594. doi:10.1046/j.1365-3059.1999.00369.x 